\title{
The Glazed Tile Techniques of the Seljuk and Beylik Periods
}

\author{
İsmail Yardımc1 \\ Usak University, Usak, Turkey
}

\begin{abstract}
The word "tile" originates from Persian and means "China" or "Chinese work". In the Ottoman language, the word "tile" also means "Chinese work", or "belonging to China". The art of Turkish tiles occupies a place of prominence in the history of Islamic art. Its roots can be traced at least as far back as the Uygurs of the eighth and ninth centuries. Its subsequent development was influenced by the Karakhanids, the Ghaznavids, and (especially) Iranian Seljuk art. With the Seljuks' victory over the Byzantines at Malazgirt in 1071, the art followed them into Anatolia and embarked upon a new period of strong development fostered by the Anatolian Seljuk sultanate. The first major development in the art of tile-making occurred primarily in Anatolian Seljuk architecture. Various techniques have been used in the art of tiles which gave hundreds of samples for centuries. This study explores the glazed tile techniques used in the production of the Seljuk and Beylik periods.
\end{abstract}

Keywords: Seljuk and Beylik periods, glazed tile, glazed brick, tile decoration, glazed tile techniques

\section{Introduction}

The Great Seljuks made variations in glazed tile techniques, and the Seljuks of Anatolia made original developments in that art. Until the 18th century, Turkish ceramic art and its products were called "evani", meaning pottery, and "kâşi”, a word of Persian origin, meaning "of Kâşan", the city that became the center for ceramics during the period of Great Seljuks. The Turkish emperor, Yavuz Sultan Selim (Selim I) brought Chinese ceramic products back from a military campaign in Iran. Since Chinese porcelain was renowned, and Chinese ceramics had an influence on Turkish ceramics, they were called "çini”, meaning "of China". Today, the ceramic pieces in various geometric shapes that decorate the interior and exterior facades of buildings are called çini (tiles), while objects of everyday use are called ceramics. The different types of tiles and ceramics that were developed and used during the Anatolian Seljuk and Ottoman periods were made using a variety of techniques (Satır, 2007, pp. 3-4).

During the Beylik and Seljuk periods, unglazed tile and ceramics were very common in Anatolia. There were also unglazed ceramics (fired earthenware), which were used in the Near East, Mesopotamia, Iran, and Syria, in the Great Seljuks period and by Artukians in Southeast Anatolia, before being used in Anatolia. Glazed tile art can be considered to have started with the glazed brick, which has been used in architectural structures since the Uygurs. Other glazed tiles were developed following this prototype.

The techniques used in the production of Seljuk and Beylik period glazed tiles include glazed brick, monochrome glazed tile, underglaze, gilding, the luster technique, the minai technique, glazed tile mosaics, relief molding, colored glaze, and the faux mosaic technique.

\section{Glazed Brick}

This relatively easy technique entails coating of one of the narrow sides of a brick with glaze and then 
firing it. Glazed brick may also be cut by brick layers into different shapes and sizes and used in this fashion (R. Arık \& O. Arık, 2008, p. 15).

The most frequently encountered type of architectural decoration from the Anatolian Seljuk period involved the use of glazed brick in which glazed (and also unglazed) bricks were arranged to produce a variety of patterns, mostly on the facades of buildings (see Figures 1-2). Mosques, mescits (small mosques), and minarets were decorated with turquoise and purple and reddish glazed brick to produce a variety of geometric compositions and kufic inscriptions (Ozel, 1999, p. 86). Turquoise was the most frequently used color for glaze although cobalt blue, eggplant violet, and sometimes black were also popular. Glazed bricks were often used in conjunction with unglazed red bricks to form complex patterns, such as the dome decoration of the Ulu Mosque in Malatya (1247). Examples of glazed brick minarets are the Taş Madrasa (Aksehir, 1250), Yivli Minaret (Antalya, late 13th century), Sahib Ata Mosque (Konya, 1258), the Gök Madrasa and Çifte Minareli Madrasa (Sivas, 1272), and Afyon Ulu Mosque and the İnce Minareli Madrasa (Konya, 1264).

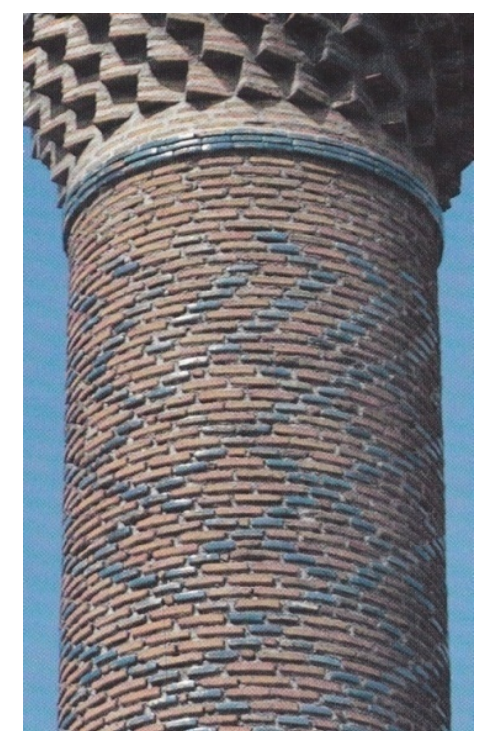

Figure 1. Glazed brick, Afyon Ulu Mosque. Source: Afyon (1272).

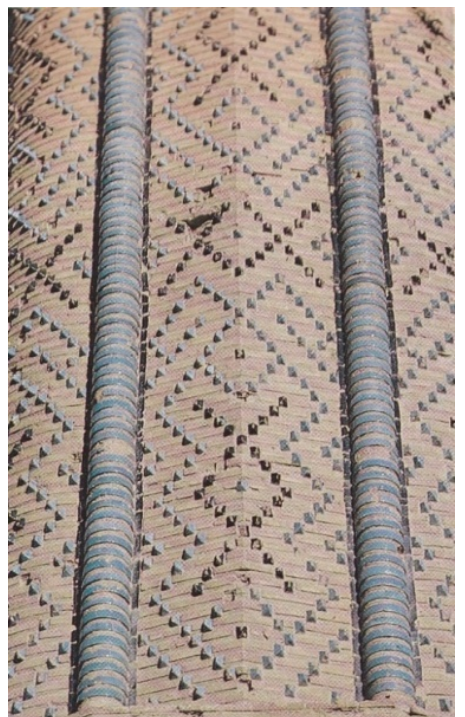

Figure 2. Glazed brick, İnce Minareli Madrasa (Konya, 1264). Sourece: Öney (1987, p. 49). 


\section{Monochrome Glazed Tiles}

Monochrome glazed tiles are produced by applying a transparent or opaque glaze to tile biscuits of varying sizes. The glaze is usually applied without a primer. Turquoise, purple (aubergine), dark blue, white, and green are frequently used on this type of tile. In the Seljuk and Beylik periods, the technique was applied to square, rectangular, hexagonal, eight-pointed star, cross-shaped, lozenge, and butterfly-shaped tiles. An important point to make at this juncture is that there is a different technique that produces results similar to monochrome glazing. In this technique, monochrome dye is applied to the tile biscuit, which is later glazed and fired. This is a form of underglaze painting. While it produces similar results, it should not be mistaken for monochrome glazing. Monochrome glazed tiles were used extensively on both religious and public buildings as well as palaces in the Seljuk and Beylik periods (Çeken, 2008, p. 15) (see Figure 3).

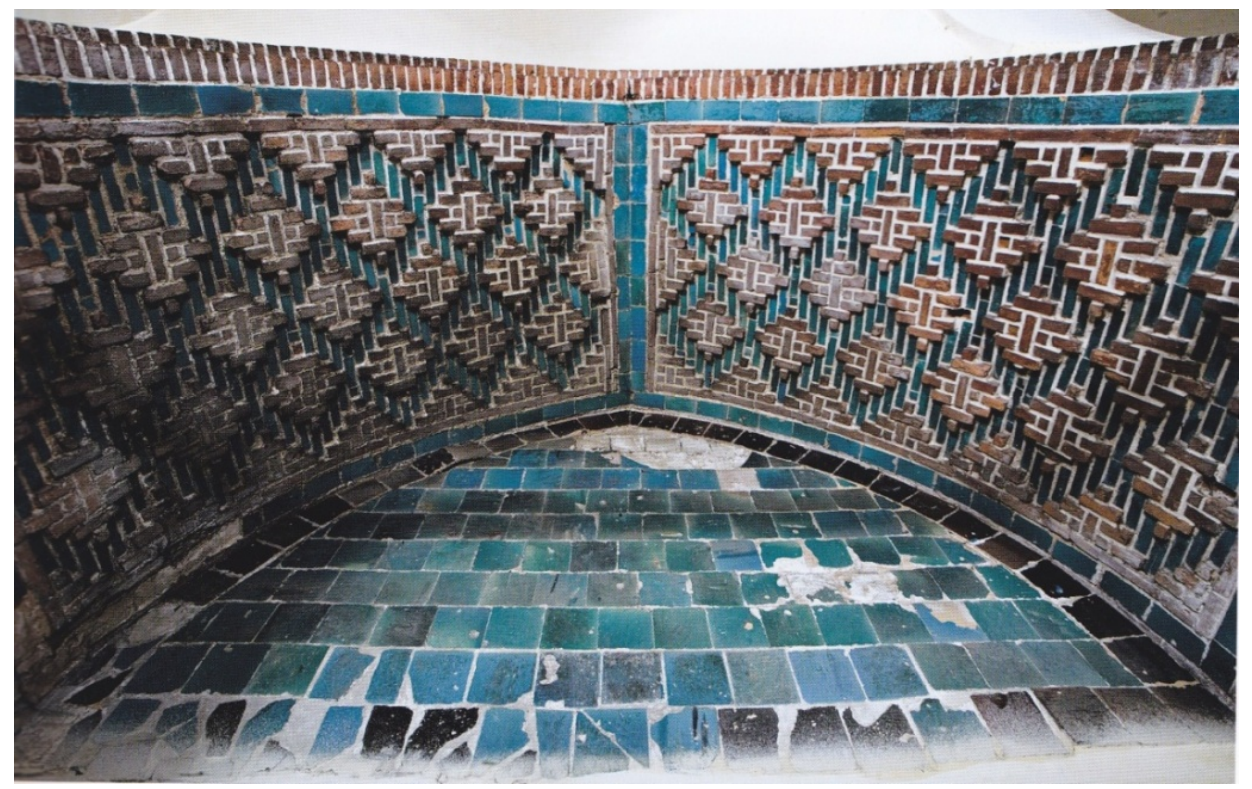

Figure 3. Monochrome glazed tile and glazed brick, Arch at the atrance from the mosque to the tomb in Gök Madrasa, Amasya. Source: R. Arık and O. Arık (2008, p. 133).

Monochrome glazed tiles were glazed by obtaining the dark blue glaze from cobalt, turquoise from copper oxide, eggplant purple from manganate, black from a mixture of manganese and copper oxide, yellow from antimony (a nonferrous metal used to harden metals such as tin and lead), and the white from tin oxide (Satır, 2007, p. 5).

Monochrome glazed tile panels were used to cover the interior walls of Seljuk works, creating a visual riot of colored glazed brick decoration on arches, vaults, 1wans, domes, and squinches (dome transitions).

\section{Underglaze}

This decoration technique entails the application of heat-resistant paints to clay biscuits and then firing them with either a colored or a colorless transparent glaze. Since the glaze is transparent, the painted decoration is visible underneath. Underglaze pigments used with transparent glaze were black, brown, green, blue, turquoise, dark blue, and purple (aubergine). Silhouetting is a technique of underglaze where black decoration (using chrome oxide) is applied under a purple transparent glaze. This is a much sought after form of underglaze. There are ceramics with cobalt blue decoration applied under turquoise transparent glaze (Y1lmaz, 2000 , p. 155), as well as black patterns used under cobalt blue transparent glaze. While underglaze tiles are 
typically used in the decoration of palaces, they are also seen on some religious and public architecture (R. Arik \& O. Arık, 2008, p. 15).

Fine examples of these tiles have been discovered at the excavations of the Kubad Abad Palace in Beysehir, where the tiles are decorated with plant motifs as well as with figures of human beings and animals (see Figure 4). Typically, the tiles are white, eight-pointed stars and have delicate figural paintings of humans and animals, including some of the best in Anatolian Seljuk representational art. Painted with an underglaze in turquoise, green, purple, and blue, these figural tiles are set on a back ground of cruciform turquoise tiles with arabesque motifs in black.
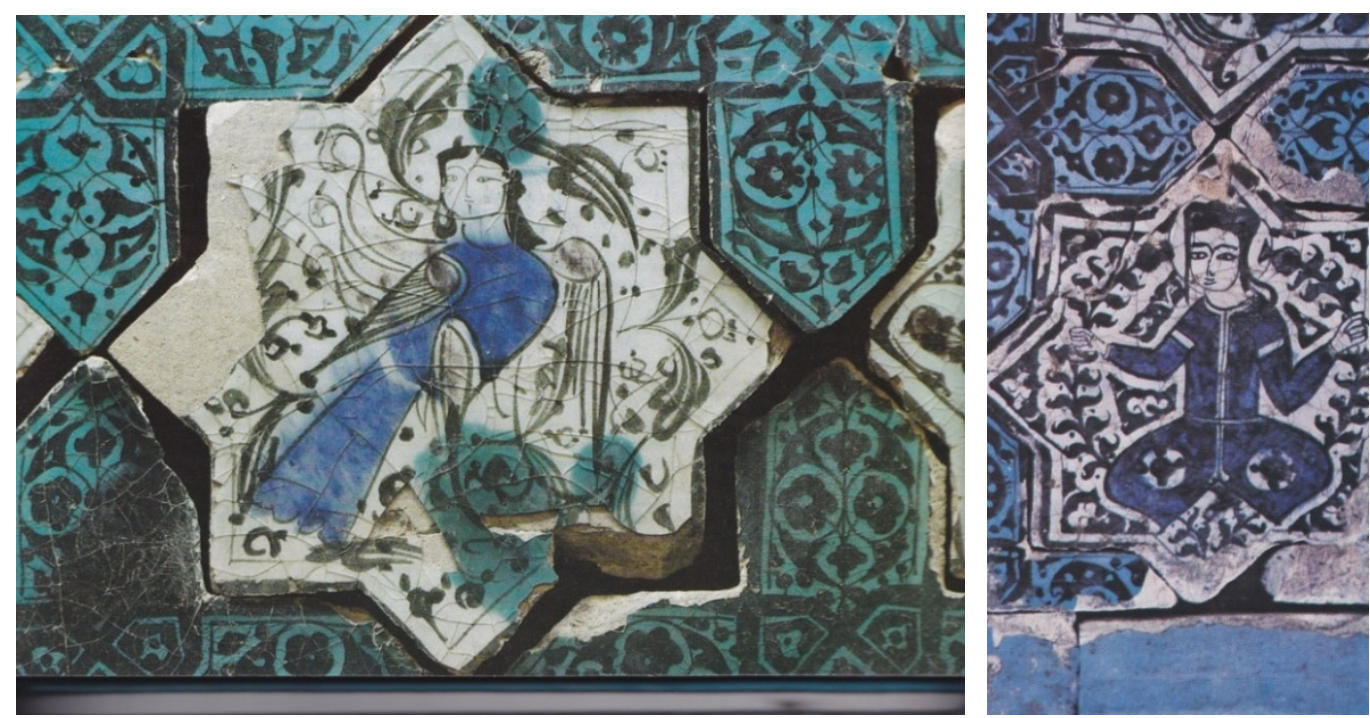

Figure 4. Underglazed painted tiles of the Kubad Abad Palace in Beysehir, Konya, 1272. Source: R. Arık and O. Arık (2008, p. 133).

\section{Gilding}

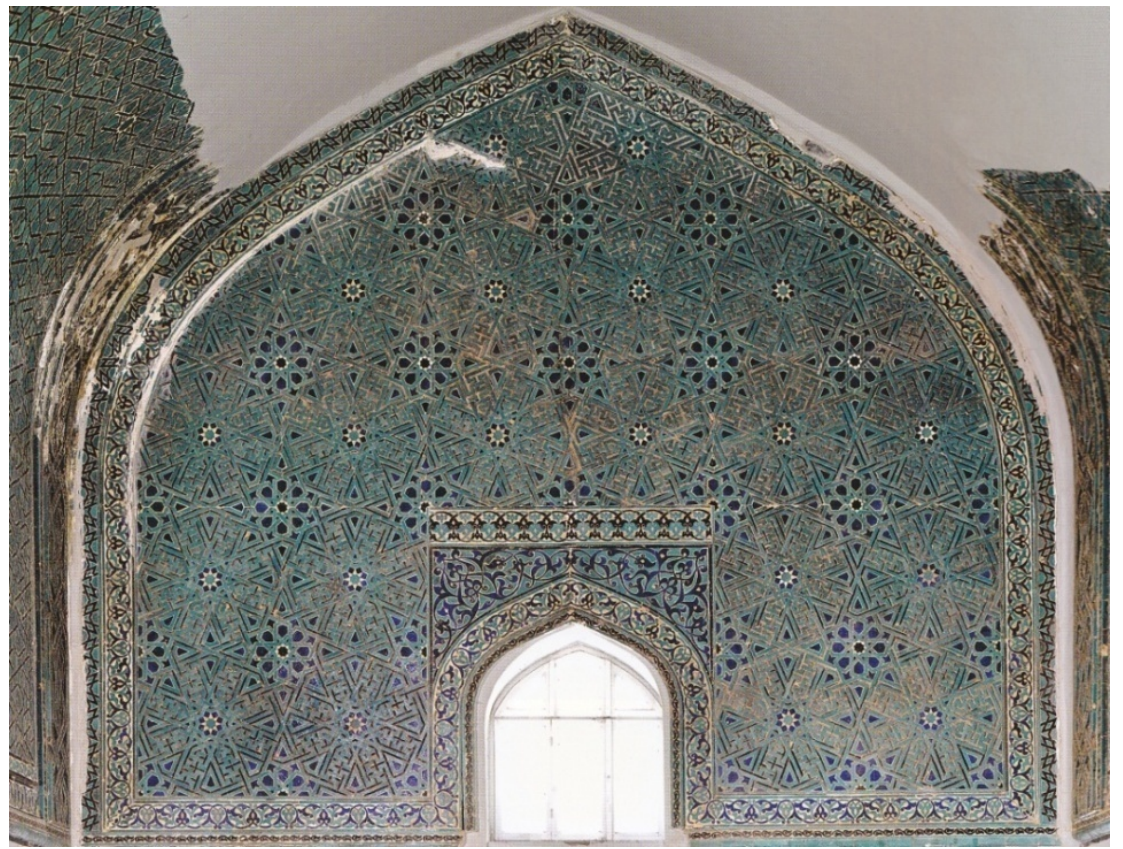

Figure 5. Interior of the eywan and the gilded tiles at the Karatay Madrasa in Konya. Source: R. Arık and O. Arık (2008, p. 87). 
This process entails the application of gold leaf to glazed tiles. Gold leaf is cut to the desired decorative pattern and applied with a brush to the tile, which is refired at a very low temperature kiln to set the leaf in place. Gilding was typically used by the Anatolian Seljuks on monochrome turquoise and green tiles. Gilding, however, can also be combined with other techniques, such as minai, where the decoration is painted onto the glaze. With gilding, which is an overglaze technique, the gold leaf may peel off in time. While only a few examples of gilded ceramics have survived from the Anatolian, during the Seljuk period and the Beylik period gilded ceramics were relatively abundant (Çeken, 2008, p. 15). Examples with traces of gilding are rare today (see Figure 5). The technique can be seen in the following examples: in the yellow and green tile piece decorated with a figure from the Kılıç Arslan II Kiosk in Konya (on display at the Karatay Museum); in the turquoise glazed hexagonal tiles of the Divriği Hospital (Yetkin, 1986, p. 165); in the prayer niche of the Kazım Karabekir Mosque; in the turquoise glazed medallion located in the Çinili Kiosk Museum (Kerametli, 1973, p. 10).

\section{Luster Technique}

In this method, the surface of glazed tiles is covered with a thin layer of metal oxides, such as silver and copper oxides. Then they are fired again at a low temperature. The technique, which requires more than one firing, is particularly labor-intensive and time-consuming. In the first firing, the biscuit and glaze, and in the second firing, the luster is cured. Luster can be applied onto all kinds of glaze (Caiger-Smith, 1985, p. 225). Luster can also be applied to transparent and colorless glazes (Morgan, 1994, p. 163), but the best results are obtained by applying it on top of an opaque white glaze. After luster is applied, the tile is placed in a relatively low temperature kiln with an oxygen reducing atmosphere. Here the metal oxides fuse with the softened glaze and form a thin film. After cooling, the soot that forms on the tile is wiped off with a damp cloth, and from beneath emerges a gold sheen that changes from yellow and ruby red, to amber, green, and brown depending on the viewing angle. The pigments create different colors and textures depending on the intensity and duration of oxygen reduction in the kiln, and how slowly the tiles were cooled after their firing (Morgan, 1994, p. 163).

The best Anatolian Seljuk luster tiles use opaque white glaze under the luster layer (see Figure 6). The luster is applied on top of turquoise, purple, green, and dark blue glazes. In all the Seljuk architecture, the greatest variety of luster tiles is to be found at the Kubad Abad palace in Konya. The tiles of the Kubad Abad Palace, the walls of which are covered with stars and cross-shaped human and animal figures, are important examples of this technique.
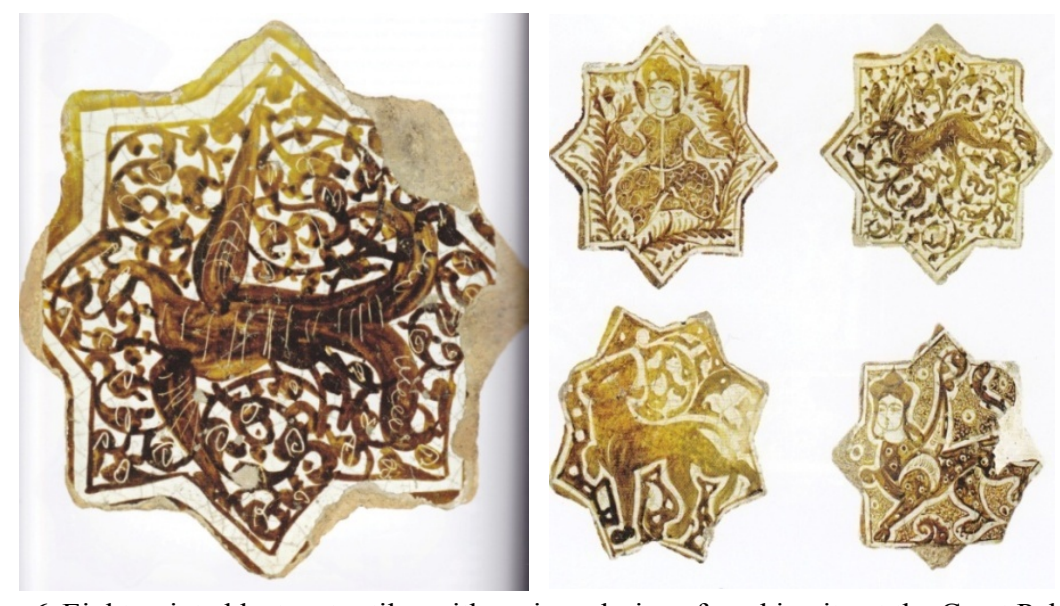

Figure 6. Eight pointed luster star tiles with various designs found in-situ at the Great Palace in Kubad Abad. Karatay Museum Konya. Source: R. Arık and O. Arık (2008, p. 328). 
Other fine examples of luster tiles can be seen in the Alanya Palace (Y1lmaz, 2000, pp. 155-165), at Hasankeyf (M. O. Arık, 2003, p. 243), in the Kayseri Museum (Bozer, 2005, pp. 12-13), and in the Kütahya Museum (Altun, 1981-1982, p. 325) (Çeken, 2008, p. 15).

\section{Minai (Enamel, Mina’i) Technique}

Minai is a unique first used by the Seljuks on tiles and ceramics. It uses many different colors and produces a high quality tile or ceramic. Abu'l Quasim refers to this technique as "seven colors" (heft renk). "Mina" is a Persian word referring to pigments made from colored frit (Develioğlu, 1993, p. 649). Western collectors of these items have thus referred to them as "mina' $i$ ware", and this name is popularly used. In recent years, the technique has also been called enamel and overglaze painted, but none of these terms does justice to the complexity of the technique (R. Arık \& O. Arık, 2008, p. 19).

Producing minai tiles is onerous and time-consuming. Of particular importance is the preparation of minai pigments to be applied over the glazed object. These pigments are made from frit, various oxides, and vinegar or molasses for viscosity. The technique entails the application of an initial glaze (usually white) on greenware. This is typically decorated using turquoise, cobalt, blue, and green (Bernsted, 2003, pp. 44-47), and then fired. Later, the item is removed from the kiln and redecorated using red, black, brown, and white colored enamels, and sometimes gilding and silvering. It is then refired in a relatively low temperature kiln. The technique created decorations with crisp lines, enabling craftsmen to achieve a high degree of detail. The first glaze, in addition to opaque white, could be opaque turquoise, blue, or dark blue. A variation of the minai technique is known as lajwardina. In this technique, the initial glaze contains no colors other than a uniform dark blue. All coloring is done as overglaze using only red, white and gilding or silvering (Çeken, 2008, p. 19).

The most common patterns and designs in artistic tile panels from this time were stars, crosses, squares and diamonds, accompanied by throne scenes representing court life, various hunting scenes and especially flowers. However, the most interesting figures are the various animals related to hunting and the imaginary or magical animals. Such creatures as the sphinx, siren, single, and double-headed eagles, singles, and paired peacocks, paired birds flanking the tree of life, and dragons create a magical world of the imagination. They are all symbolic representations of the rich figural world of the Seljuks (Ozel, 1999, p. 88). Fine examples of these tiles can be seen in the Konya Aladdin Kiosk (the Kılıç Arslan II Kiosk) (see Figure 7).
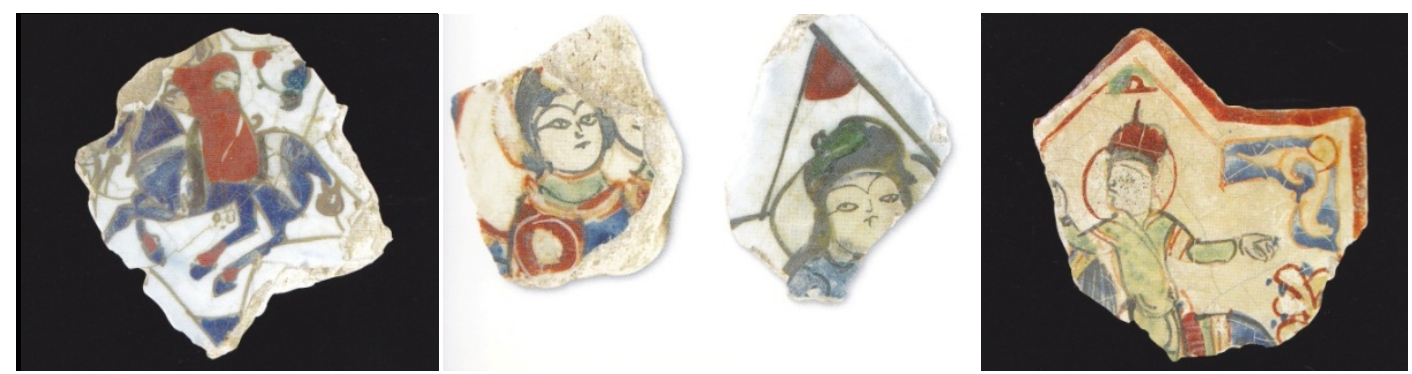

Figure 7. Examples of Minai tiles Konya Aladdin Kiosk (the Kılıç Arslan II Kiosk). Konya. Source: Öney (1987, p. 35).

\section{Glazed Tile Mosaics}

Tile mosaic decoration became highly developed in Anatolia during the Seljuk period. It is a complex and visually diversified technique, generally applied to such interior surfaces as domes, squinches, arches, panels, and mihrabs. Tiles in turquoise, and less frequently in purple, cobalt blue, and black glazes were cut to the required shape to form a decorative composition. The cut pieces were placed, according to a design, in a 
mosaic-like pattern (Ozel, 1999, p. 87). Custom glazed tile pieces in the form of medallions, stars, cones, etc., have also been produced. To create the mosaic pattern, small pieces of tile are laid down on a flat or curved surface. Later, gypsum plaster is poured on the back of the pieces to pieces to seal them in place. Once the plaster is dry, the mosaic can be mounted on the surface it was intended for. Glazed tile mosaics have been widely used as architectural decoration owing to their ability to conform to both flat and curved surfaces (Çeken, 2008, p. 20) (see Figure 8).

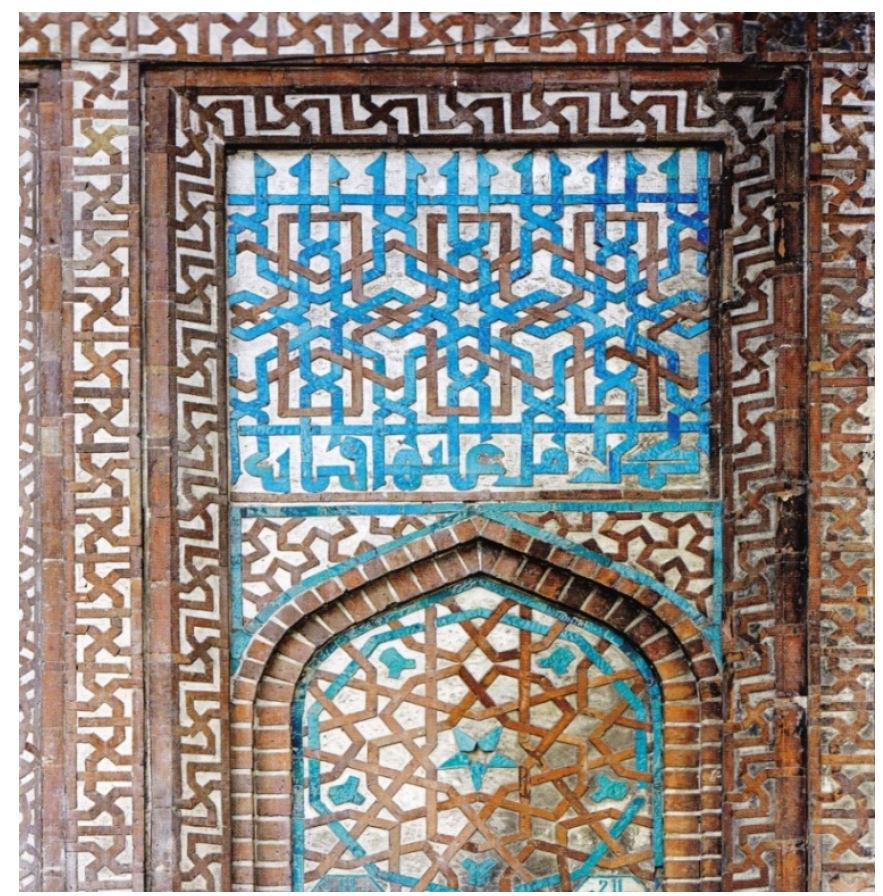

Figure 8. Glazed tile müsaics of the window on the right of the right on the etrance at the Tomb of Keykavus in Sivas. Source: R. Arık and O. Arık (2008, p. 51).

Mosaic tile compositions range from geometric and floral patterns to examples of calligraphy. Glazed tile mosaics have also been used together with brick, gypsum, or stone to create rich compositions of different colors and textures. The most popular colors were turquoise, cobalt blue, eggplant violet, and black.

Examples of Anatolian Seljuk buildings decorated with mosaic tile include the Karatay Madrasa in Konya, the Aladdin Mosque in Konya, the Gok Madrasa and Mosque in Sivas and the Malatya Grand Mosque in Malatya.

\section{Relief Molding Technique}

This technique entails the production of relief tiles, using special molds and/or sculpting after the moulding. The technique, which, based on findings unearthed so far, was used only on monochrome and underglaze tiles in the Anatolian Seljuk and Beylik periods, was applied to luster and minai tiles outside of Anatolia (R. Arık \& O. Arık, 2008, p. 20) (see Figure 9). The technique was typically employed on tiles with bands of calligraphy using white and dark blue colored glaze, but monochrome relief molded tiles are also to be found in Anatolia.

Examples of the technique can be seen in the Kubad Abad Palace, the Aladddin Mosque, and the Karaarslan Tomb in Konya. Examples of the monochrome relief molded tiles are also present on the sarcophagus inscription of Mevlana Celaleddin Rumi's Tomb. 


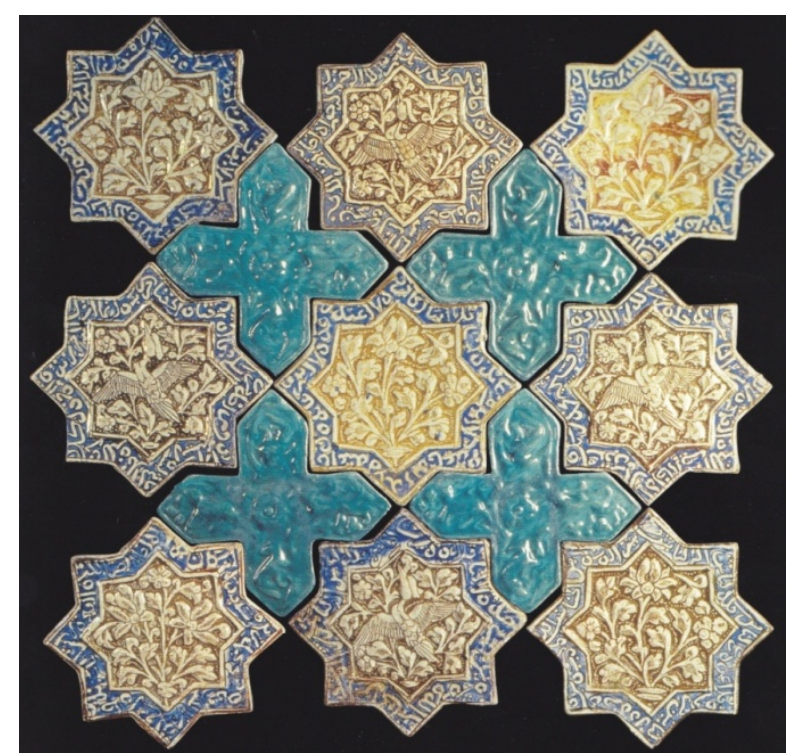

Figure 9. Examples of glazed tiles with relief molding technique, Iran. Art of Islam Museum, Berlin. Source: Öney (1987, p. 54).

\section{Colored Glaze Technique}

Colored glazes can be applied onto the plates in several ways. The biscuit is generally red in color. In the first method, the contours of the desired pattern are drawn onto the biscuit using a glaze with chrome or manganese oxide and sugar. Later, the pattern is colored using blue, purple, green, yellow, white, or red colored opaque glazes and fired. During firing, the contours rise and keep the other colors from mixing. A different method is seen mainly in the Early Ottoman period. The pattern to be colored is either carved onto the biscuit, or pressed with a face mould. Later, the recesses created by the carving or the mould are filled with different colored glazes, and the biscuit is fired (Yetkin, 1986, pp. 205-207) (see Figure 10).

This technique, which is not seen until the first half of the 15th century in Anatolian glazed tiles, became popular mainly in the Early Ottoman period and was further developed following this era. In the Beylik period, outside of Ottoman territory, the best example is the prayer niche of the Karamanoglu Ibrahim Bey Imaret (complex) (R. Arık \& O. Arık, 2008, p. 21).

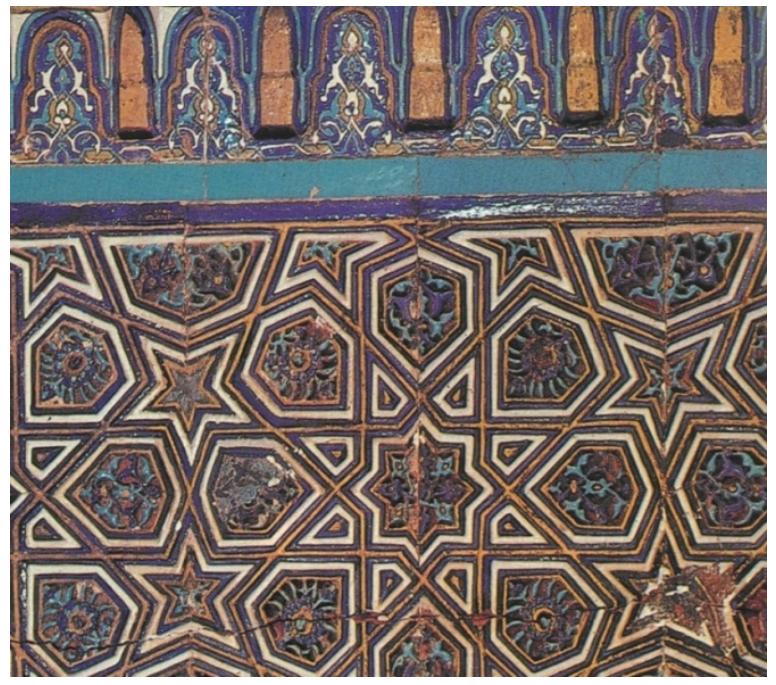

Figure 10. Colored glazed tile decoration of Bursa Green Mosque. Source: Ozel (1999, p. 86). 
In addition to these techniques, the faux mosaic technique (glaze engraving) was used during the Seljuk period. This technique entails engraving a glazed tile to reveal the underlying clay. The engraving is done according to a pattern, thus creating a mosaic effect (see Figure 11). Examples of this technique can be seen in the Malatya Grand Mosque and the Sahipata tomb in Konya.

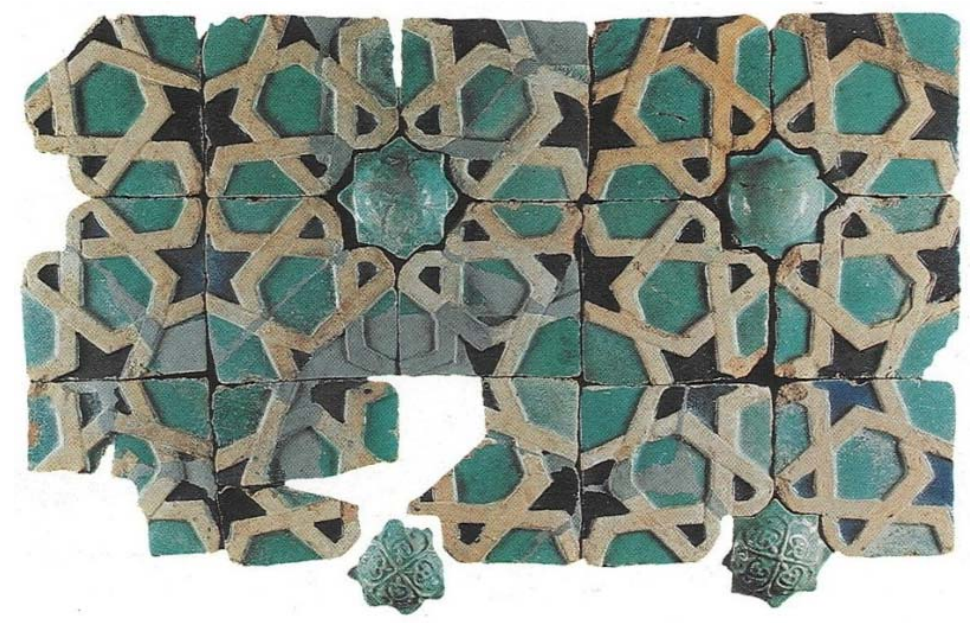

Figure 11. Example of the faux mosaic technique. Tile decoration of Bursa Green Mosque. Source: Öney (1987, p. 36).

\section{Conclusions}

The Turkish interior and exterior architectural ornamental tile art form and the continuous development of Anatolian Turkish architecture have been shown. The various techniques of this ornamental art always create a colorful atmosphere, based on the architecture.

This art form was very common in the Anatolian Seljuk architectural monuments of various types and it shows a great improvement over its continued existence until today. The tile decoration of each period, while maintaining the technical virtues of the previous period, has enriched the tradition with new technical inventions and colors.

In Anatolian Seljuk architecture, religious buildings are decorated with the mosaic tile technique. The first examples of bricks and glazed bricks were used, but in a short period of time, all the surface finishing of glazed mosaic tiles reached a superior level. In the Beylik period, the use of tiles was not as majestic as it was in the Seljuk period. However, in some examples, this art is still being seen as successful. In sum, the tile art techniques of the Seljuk and Beylik periods inspired the artists of the Ottoman period.

\section{References}

Altun, A. (1981-1982). Turkish period architecture of Kütahya (Kütahya’nın Türk devri Mimarisi). Istanbul: Kütahya Kültür Yayınları.

Altun, A., Carswell, J., \& Oney, G. (1991). Turkish tiles and ceramics, Iznik Kutahya, Canakkale. Istanbul: Sadberk Hanim Museum.

Arık, M. O. (2003). Hasankeyf: The city where three worlds meet (Hasankeyf: Üç Dünyanın Buluştuğu Kent). İstanbul: Türkiye İş Bankası Kültür Yayınları.

Arık, R., \& Arık, O. (2008). Tiles, treasure of the Anatolian soil, tiles of the Seljuk and Beylik periods (Anadolu Toprağının Hazinesi ÇiniSelçuklu Ve Beylikler Çă̆l Çinileri). Istanbul: Kale Group Editions.

Aslanapa, O. (1993). Turkish art (Türk Sanatı). Istanbul: Remzi Kitap Evi.

Bernsted, A.-M. K. (2003). Early Islamic pottery materials \& techniques. London: Archetype. INST ARCHKD 1 KEB. 
Bozer, R. (2005). Kayseri huand bath tiles (Kayseri Huand Hamamı Çinileri). İzmir: Sanat Tarihi Dergisi.

Caiger-Smith, A. (1985). Lustre pottery: Technique, tradition and innovation in Islam and the western world. London: Faber and Faber.

Çeken, M. (2008). Materials, techniques and kilns used in the productions of Seljuk and Beylik period glazed tiles. Tiles, treasure of the Anatolian soil, tiles of the Seljuk and Beylik periods (Anadolu Topră̆ının Hazinesi ÇiniSelçuklu Ve Beylikler Çă̆ Çinileri). Istanbul: KaleGroup Editions.

Develioğlu, F. (1993). Glossary of old and new letters in Ottoman Turkish (Osmanlıca Türkçe Lügat eski ve yeni harflerle). (11. Bask1). Ankara: Aydın Kitabevi.

Kerametli, C. (1973). Wall tiles Anatolian Seljuk periods (Anadolu Selçuklu Devri Duvar çinileri). Türkiyemiz Journal (Türkiyemiz), 10.

Morgan, P. (1994). Iranian stone-paste pottery of the Saljug period: Types and techniques. Cobalt and lustre, the first centuries of Islamic pottery. Oxford: Oxford University Press.

Öney, G. (1987). Ceramic tiles in Islamic architecture. Istanbul: Ada Press Publishers.

Öney, G. (1989). Arts of Beylik periods XIV.-XV. century (Beylikler Devri Sanati, XIV.-XV. Yuzyil), (1300-1453). Ankara: Turkish History Foundation Print House.

Öney, G., \& Cobanl1, Z. (2007). Art of tiles and ceramics in the Turkish period in Anatolia (Anadolu'da Türk Devri Çini ve Seramik Sanatı). Istanbul: T. R. Ministry of Culture and Tourism General Directorate of Libraries and Editions.

Oral, E. M. (2005). Development of the contemporary Turkish ceramic art (Türkiyede Çăgdaş Seramik Sanatının Gelişimi). Eskişehir: Anadolu Sanat.

Ozel, M. (1999). Turkish arts. Ankara: The Republic of Turkey, Ministry of Culture.

Porter, V. (1995). Islamic tiles. London: British Museum Press.

Satır, S. (2007, February). A current evaluation of the traditional Iznik tiles and ceramic. Design Discourse, II(3).

Yetkin, Ş. (1986). Development of the art of Anatolia, Turkish tiles (Anadolu'da Türk Çini sanatının Gelişimi). İstanbul: Istanbul Üniversitesi. Edebiyat Fakültesi Yayınları.

Y1lmaz, L. (2000). Ceramic finds from the excavation-Seljuk palace Alanya castle, I-IV. Excavation and research symposium Midle age and Turkish periods. Van, Turkey: Yüzüncü Y1l Üniversitesi. (Alanya kalesi kazıs1-Selçuklu Sarayı çini buluntuları-I, IV. Otaçağ ve Türk dönemi Kazıları ve Araştırmaları Sempozyumu Bildiriler Kitabı. Van, Turkey: Yüzüncü Y1l Üniversitesi Yayınları). 